\title{
Corrosion Testing of Carbon Steel in Acid Cleaning Solutions (U)
}

\author{
B. J. Wiersma \\ K. H. Subramanian
}

Publication Date: September 2002

DOES NOT CONTAIN
UNCLASSIFIED CONTROLLED
NUCLEAR INFORMATION

ADC \&

Reviewing

Official:S.L.west/L.R. Why

Date:

\section{Westinghouse Savannah River Company}

\section{Savannah River Site}

\section{Aiken, SC 29808}

This document was prepared in connection with work done under Contract No. DE-AC09-96SR18500 with the U. S. Department of Energy 
This document was prepared in conjunction with work accomplished under Contract No. DE-AC09-96SR18500 with the U. S. Department of Energy.

\section{DISCLAIMER}

This report was prepared as an account of work sponsored by an agency of the United States Government. Neither the United States Government nor any agency thereof, nor any of their employees, makes any warranty, express or implied, or assumes any legal liability or responsibility for the accuracy, completeness, or usefulness of any information, apparatus, product or process disclosed, or represents that its use would not infringe privately owned rights. Reference herein to any specific commercial product, process or service by trade name, trademark, manufacturer, or otherwise does not necessarily constitute or imply its endorsement, recommendation, or favoring by the United States Government or any agency thereof. The views and opinions of authors expressed herein do not necessarily state or reflect those of the United States Government or any agency thereof.

This report has been reproduced directly from the best available copy.

Available for sale to the public, in paper, from: U.S. Department of Commerce, National Technical Information Service, 5285 Port Royal Road, Springfield, VA 22161, phone: (800) 553-6847, fax: (703) 605-6900

email: orders@ntis.fedworld.gov

online ordering: http://www.ntis.gov/help/index.asp

Available electronically at http://www.osti.gov/bridge

Available for a processing fee to U.S. Department of Energy and its contractors, in paper, from: U.S. Department of Energy, Office of Scientific and Technical Information, P.O. Box 62, Oak Ridge, TN 37831-0062,

phone: (865)576-8401,

fax: (865)576-5728

email: $\underline{\text { reports@ adonis.osti.gov }}$ 
DOCUMENT: WSRC-TR-2002-00427

TITLE: Corrosion Testing of Carbon Steel in Acid Cleaning Solutions (U)

APPROVALS

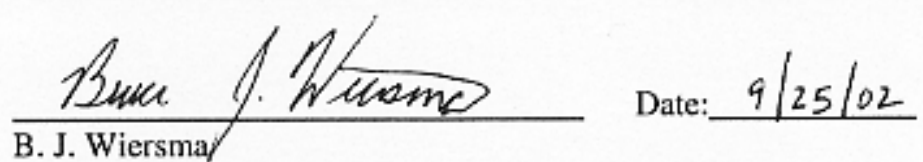

Materials Performance \& Corrosion Technology Group

Materials Technology Section

lection lube

Date: $9 / 25 / 0^{2}$

K. H. Subramanian

Materials Applications \& Process Technology Group

Materials Technology Section

Plump

Date: $9 / 25 \%$

P. E. Zap pit Technical Reviewer

Materials Applications \& Process Technology Group

Materials Technology Section

Hey T. Clade Date :9/25/02

G. T. Chgुnaler, Manager

Materials Performance \& Corrosion Technology Group

Materials Technology Section

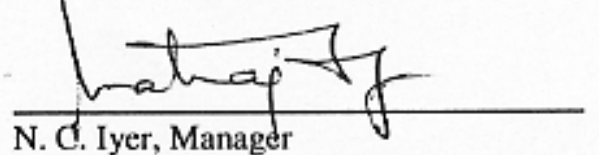

Date: $9 / 25 / 03$

Materials Technology Section

Savannah River Technology Center

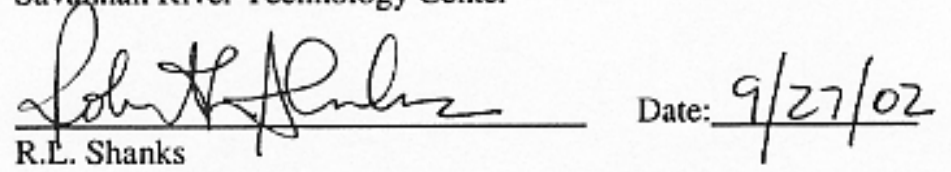

High Level Waste Engineering 


\section{Corrosion Testing of Carbon Steel in Acid Cleaning Solutions (U)}

\section{Executive Summary}

High level waste is stored in carbon steel tanks at the Savannah River Site (SRS). The site is currently in the process of waste removal from, and ultimately closure of, these tanks. One of the most time consuming steps in the waste removal process is cleaning the sludge heel from the bottom of the tanks to an acceptable residual quantity. The sludge consists primarily of metal oxides that formed after waste from the canyons was neutralized with sodium hydroxide. Since the canyon waste was originally a nitric acid solution, this acid is a prime candidate for sludge heel dissolution.

A series of exploratory tests were performed to investigate the hypothesis that the corrosion rate of carbon steel in nitric acid could be inhibited with oxalic acid. These tests were performed at two nitric acid concentrations $(0.3$ and $3 \mathrm{M})$ and three oxalic acid concentrations (4 wt. \%, 8 wt. \%, and 12 wt. \%) and were limited to the expected contact time for sludge dissolution (approximately 3 days). Carbon steels (ASTM A285 and A537) utilized in the construction of Type I, II and IIIA tanks were tested.

The general corrosion rate, as well pit depths, were measured and compared. The results of the tests suggest that oxalic acid may inhibit steel corrosion in nitric acid solutions that have concentrations on the order of $0.3 \mathrm{M}$. For short contact times, these solutions may be viable as sludge dissolution media. In contrast, essentially no passivation was observed during the first 3 days in the $3 \mathrm{M}$ nitric acid/oxalic acid solutions. Therefore, utilization of solutions with nitric acid concentrations on the order of $3 \mathrm{M}$ for sludge dissolution are not recommended. More testing at better defined sludge removal conditions (i.e., perhaps higher temperatures, longer contact times and other species present) is needed to evaluate the recommendation for utilization of the more dilute nitric acid solutions for sludge dissolution. Additional studies to investigate sludge and fissile material dissolution in these dilute nitric acid/oxalic acid solutions are also necessary.

\section{Background}

High level waste is stored in carbon steel tanks at the Savannah River Site (SRS). The site is currently in the process of waste removal from, and ultimately closure of, these tanks. One of the most time consuming steps in the waste removal process is cleaning the sludge heel from the bottom of the tanks to an acceptable residual quantity. In the past mechanical processes have been attempted with limited success. Therefore, an alternate chemical means of dissolving the sludge is being considered.

The sludge consists primarily of metal oxides that formed after waste from the canyons was neutralized with sodium hydroxide. Since the canyon waste was originally a nitric acid solution, this acid is a prime candidate for sludge heel dissolution. However, nitric acid is very corrosive to the carbon steel waste tank. An inhibitor could be added to nitric acid to reduce its corrosivity towards carbon steel yet maintain its metal oxide dissolution efficiency. The combination might provide an efficient and cost-effective means of heel removal. The corrosion rate of carbon steel in oxalic acid has been observed to decrease with time due to the formation of a passive ferrous oxalate film. Therefore, it was hypothesized that a combination of nitric acid and oxalic acid may provide the desired outcome.

At this time the dissolution rates of sludge and fissile material are not well defined. However, given the behavior of carbon steel under acidic conditions, it is expected that the process will need to be completed within a relatively short period of time (two weeks or less). 
Page 2 of 12

\section{Introduction}

A literature review of the corrosion of carbon steel in nitric acid [1,2] and oxalic acid [3-5] was performed. A brief summary of the corrosion mechanism and corrosion rates in the environments tested is presented below. No information was obtained on corrosion of carbon steel in a combined nitric acid/oxalic solution.

\section{Nitric Acid Corrosion Mechanism}

The nitric acid corrosion mechanism has been studied for many years. Although the anodic reaction is fairly simple, iron being oxidized to ferrous cation $\left(\mathrm{Fe}^{2+}\right)$, there are a number of cathodic reactions that occur in this process [1]. The cathodic reduction of nitric acid likely proceeds in five steps:

$$
\begin{aligned}
& \mathrm{H}^{+}+\mathrm{e}^{-}=\mathrm{H} \\
& \mathrm{HNO}_{3}+\mathrm{H}^{+}+\mathrm{e}^{-}=\mathrm{NO}_{2}+\mathrm{H}_{2} \mathrm{O} \\
& \mathrm{NO}_{2}+\mathrm{e}^{-}=\mathrm{NO}_{2}^{-} \\
& \mathrm{H}^{+}+\mathrm{NO}_{2}^{-}=\mathrm{HNO}_{2} \\
& \mathrm{HNO}_{2}+\mathrm{H}=\mathrm{NO}+\mathrm{H}_{2} \mathrm{O}
\end{aligned}
$$

The nitrous acid $\left(\mathrm{HNO}_{2}\right)$ that was formed in step (4) regenerates $\mathrm{NO}_{2}$ by an interaction with the nitric acid:

$$
\mathrm{HNO}_{2}+\mathrm{HNO}_{3}=2 \mathrm{NO}_{2}+\mathrm{H}_{2} \mathrm{O}
$$

Thus the reaction becomes autocatalytic. Ammonia salts are also formed during the cathodic reaction. The ammonia salts decompose to form $\mathrm{N}_{2}$ and NOx compounds by the following reactions.

$$
\begin{aligned}
& \mathrm{NH}_{4} \mathrm{NO}_{2}=\mathrm{N}_{2}+2 \mathrm{H}_{2} \mathrm{O} \\
& \mathrm{NH}_{4} \mathrm{NO} 3=\mathrm{N}_{2} \mathrm{O}+2 \mathrm{H}_{2} \mathrm{O}
\end{aligned}
$$

Thus formation of $\mathrm{NO}_{2}, \mathrm{NO}, \mathrm{N}_{2} \mathrm{O}$ and $\mathrm{N}_{2}$ (i.e., a brown gas should be emitted) due to the cathodic reaction is expected.

Iron differs from many metals in that the corrosion rate increases with acid concentration, up to approximately $6 \mathrm{M}$, and then decreases dramatically. Uhlig reports that the corrosion rate in $1 \mathrm{M}$ nitric acid at $25 \mathrm{C}$ is approximately 2 inches per year [2]. The corrosion rate increases to a maximum of approximately 13 inches per year at $6 \mathrm{M}$ nitric acid. However, at higher concentrations a passive ferric oxide film forms on the surface and corrosion rate is reduced significantly. At $15 \mathrm{M}$ nitric acid the corrosion rate is 0.02 inches per year. Unless the ferric oxide film is disturbed, (i.e., mechanically ruptured or reduced), the carbon steel surface will remain passivated.

The highest concentration of nitric acid that was tested was 3 M. Addition of more acid would likely hinder the dissociation of the oxalic acid. A comparison of the corrosion rate of steel in nitric acid alone and that for steel in nitric acid and oxalic acid at various concentrations will be made to determine if the high nitric acid corrosion rates are decreased.

\section{Oxalic Acid Corrosion Mechanism}

The corrosion of iron in oxalic acid has also been investigated for many years [3]. The anodic reactions are reported to be:

$$
\begin{aligned}
& \mathrm{Fe}=\mathrm{Fe}^{2+}+2 \mathrm{e}^{-} \\
& \mathrm{Fe}=\mathrm{Fe}^{3+}+3 \mathrm{e}^{-}
\end{aligned}
$$




\section{Page 3 of 12}

The cathodic reaction is the reduction of hydrogen ion to hydrogen gas. Two other reactions occur that impact the corrosion rate.

$$
\begin{gathered}
\mathrm{Fe}^{3+}+3 \mathrm{C}_{2} \mathrm{O}_{4}{ }^{2-}=\mathrm{Fe}\left(\mathrm{C}_{2} \mathrm{O}_{4}\right)_{3}{ }^{3-} \\
2 \mathrm{Fe}\left(\mathrm{C}_{2} \mathrm{O}_{4}\right)_{3}{ }^{3-}=2 \mathrm{FeC}_{2} \mathrm{O}_{4}+3 \mathrm{C}_{2} \mathrm{O}_{4}{ }^{2-}+2 \mathrm{CO}_{2}
\end{gathered}
$$

The ferric oxalate anion from equation 11 is soluble and is recognizable by its lime green color in solution. This anion decomposes photocatalytically over a period of days, depending on the radiation intensity in the visible range. Consequently, a ferrous oxalate complex precipitates on the surface of the steel and markedly depresses the iron corrosion rate and passivates the steel. Thus, if ferric oxalate is not present near the surface, or there is not enough light, the process of passivation will be hindered.

Corrosion rates in oxalic acid are generally much less than those in nitric acid. At room temperature, the corrosion rate of carbon steel in $4 \mathrm{wt} . \%$ and $8 \mathrm{wt} . \%$ oxalic acid is on the order of 20 to 40 mpy for tests conducted between 2 to 6 days [4]. The corrosion rate triples in the same solutions if the temperature is increased to $50{ }^{\circ} \mathrm{C}[5]$. Coupon tests in the same solutions at higher temperatures $\left(85\right.$ and $\left.95^{\circ} \mathrm{C}\right)$, but for a longer time (14 days), actually had a lower corrosion rate of approximately $30 \mathrm{mpy}$. This last data shows the effectiveness of the passive ferrous oxalate film once it has formed.

A series of exploratory tests were performed to investigate the hypothesis that the corrosion rate of carbon steel in nitric acid could be inhibited with oxalic acid. These tests were performed at two nitric acid concentrations $(0.3$ and $3 \mathrm{M})$ and three oxalic acid concentrations (4 wt. \%, 8 wt. \%, and 12 wt. \%) and were limited to the expected contact time for sludge dissolution (approximately 3 days). Carbon steels utilized in the Type I, II and IIIA tanks were tested. However, the effect of solution temperature and the effect of sludge on the corrosion rate were not tested at this time.

\section{Experimental}

Laboratory coupon immersion tests were conducted in accordance with ASTM standard practice G31 [6]. The tests were performed on two types of carbon steel: ASTM A285 Grade C (material of construction for Type I and II waste tanks) and ASTM A537 Class 1 (material of construction for the Type IIIA waste tanks). The following steps were performed to complete the testing.

\section{Pre-test Characterization of Coupons}

The coupons were characterized prior to testing to provide a baseline for comparison to the post-test results. This process involved photographing, measuring the dimensions, and weighing of the coupons. The standard practice recommends measuring the dimensions to the nearest 0.001 inches and the weight was measured within $0.0001 \mathrm{~g}$.

Figure 1 shows a typical A537 coupon. The coupons were nominally 2 x 1 x 0.25 inches and contained a 0.2 inch diameter hole near the top of the coupon. The coupons were ground and polished to a 600-grit finish on each surface. Each coupon was stamped with the type of material and a unique identification number. On average the coupons weighed approximately 60 grams. 
Page 4 of 12

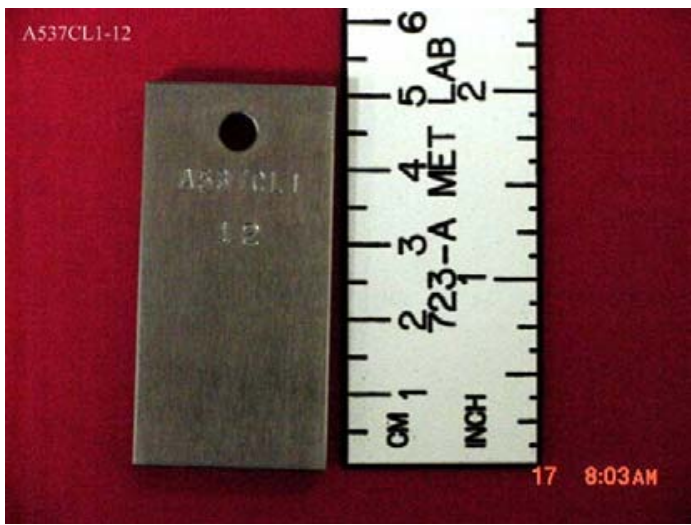

Figure 1. A537 Carbon Steel Coupon Prior to Testing.

\section{Performance of Coupon Immersion Tests}

The coupons were completely immersed in a nitric acid solution or in a combination of nitric acid and oxalic acid. Table 1 shows the matrix with the various compositions that were utilized for the tests. Solutions were prepared utilizing reagent grade concentrated nitric acid, oxalic acid di-hydrate crystals and de-ionized water. The tests were conducted at room temperature (approximately $25^{\circ} \mathrm{C}$ ) for 72 hours. However, in one case ( $3 \mathrm{M}$ nitric acid $+8 \mathrm{wt}$. \% oxalic acid) the test was extended to 9 days.

The tests were conducted in 1-liter polyethylene bottles that were vented to prevent pressure build-up due to gas generation. Two coupons were suspended in each solution with Teflon ${ }^{\mathrm{TM}}$ string. Each coupon was degreased with acetone prior to immersion in the test solution.

Table 1. Solution Test Matrix for Coupon Tests

\begin{tabular}{|l|l|l|l|l|l|l|c|c|}
\hline Solution & 1 & 2 & 3 & 4 & 5 & 6 & 7 & 8 \\
\hline $\begin{array}{l}\text { Nitric } \\
\text { Acid (M) }\end{array}$ & 3 & 3 & 3 & 3 & 0.3 & 0.3 & 0.3 & 0.3 \\
\hline $\begin{array}{l}\text { Oxalic } \\
\text { Acid } \\
\text { (wt.\%) }\end{array}$ & 0 & 4 & 8 & 12 & 0 & 4 & 8 & 12 \\
\hline
\end{tabular}

Post-test Analysis of Coupons and Test Solutions

At the completion of the tests, the following analyses were performed: qualitative characterization of the solution, macro-photographs of the coupons, optical microscopy of the coupon surface, X-ray diffraction (XRD) analysis of the corrosion products, and weight loss measurements.

The test solutions, after removal of the coupons, were qualitatively evaluated for color, presence of solids and $\mathrm{pH}$. Macro-photographs of the coupons were taken to evaluate gross changes in the coupon surface and perform a cursory evaluation of the forms of corrosion (e.g., general, pitting, etc.). Deposits or corrosion products were next removed from the surface and submitted for XRD analysis. The samples were then cleaned with Clarke's solution and the surface morphology of the coupon was characterized by light microscopy. Weight loss from each coupon was then measured to assess the corrosion rates in the various test solutions. 


\section{Page 5 of 12}

\section{Results \\ Qualitative Solution Characterization}

Table 2 provides a summary of the solution characterization results. In general the observations were independent of the material type. During the first few hours of the test, coupons in solutions with $3 \mathrm{M}$ nitric acid began to react violently. These solutions turned dark brown in color, a foam appeared at the top of the solution, and a brown gas was emitted from the bottle. The color was likely due to the presence of iron in solution, while the brown gas is likely due to the generation of $\mathrm{NO}_{\mathrm{X}}$ compounds. Although it was not measured, the temperature of these solutions increased significantly. After one day, the temperature of the bottle had returned to room temperature. Several of the samples were also observed to have fallen to the bottom of the bottle after 1 day. The coupons in solution in $0.3 \mathrm{M}$ nitric acid solution did not appear to react violently. No emission of gas or increase in temperature was observed for these solutions. The $0.3 \mathrm{M}$ nitric acid solution remained clear through most of the testing, although near the end of the test, the bottom of the solution had a dark brown appearance. The $0.3 \mathrm{M}$ nitric acid solutions that also contained oxalic acid at any of the tested concentrations, turned a lime green as the tests progressed. The literature suggests that this is a result of soluble ferric oxalate forming in the solution.

Solids at the bottom of the test solution were only observed in two cases. In the $3 \mathrm{M}$ nitric acid solutions, the solids were dark and rusty in appearance. These solids were likely iron oxides that precipitated once the solubility of the compound in the solution was exceeded. The other case involved the $0.3 \mathrm{M}$ nitric acid/12 wt.\% oxalic acid in which the particles had a crystalline appearance. These solids may have been oxalic acid crystals [4] or an iron oxalate compound that precipitated due again to solubility issues.

A slightly higher $\mathrm{pH}$ was observed in solutions that contained nitric acid only than in solutions that contained a combination of nitric and oxalic acids. The $\mathrm{pH}$ in both the $3 \mathrm{M}$ nitric acid solution had increased significantly compared to the initial $\mathrm{pH}$ and there had also been a slight increase in the $\mathrm{pH}$ for the $0.3 \mathrm{M}$ nitric acid solution. This suggests that a significant amount of hydrogen consumption occurs in these solutions. The data also indicate that as the concentration of oxalic acid increased the $\mathrm{pH}$ decreased. This observation could be related to the initially higher hydrogen ion concentration for the solutions with higher oxalate concentrations, rather than the lower concentration solutions actually consuming more hydrogen ions.

\section{Macroscopic Observations of Coupons}

Figures 2- 4 are photographs of the coupons after they were removed from solution, but prior to cleaning. In general, both types of material had the same appearance. Figure 2 shows coupons that were immersed only in nitric acid $(0.3 \mathrm{M}$ and $3.0 \mathrm{M})$. The coupons that had been immersed in the $3 \mathrm{M}$ solution exhibited severe general attack and an indication of crevice attack where the teflon string had been inserted into the hole. The coupons that were immersed in the $0.3 \mathrm{M}$ solution exhibited light general attack and had no evidence of crevice attack near the hole. There was an insignificant amount of corrosion product on these coupons exposed to the more dilute acid.

Figure 3 shows coupons that were immersed in $3 \mathrm{M}$ nitric acid and various concentrations of oxalic acid. All coupons exhibited severe general attack and crevice attack where the teflon string had been inserted into the hole. In all cases, the corrosive attack had eaten through the top edge of the coupon and the coupon had fallen to the bottom of the bottle. Further crevice attack ensued on the edge that the coupon had rested. For the most part the coupons were free of iron oxides and had a few crystalline deposits. However, the A285 sample that had been immersed for 9 days, exhibited a significant number of yellowish-green crystalline deposits.

Figure 4 shows coupons that were immersed in $0.3 \mathrm{M}$ nitric acid and various concentrations of oxalic acid. These coupons exhibited light surface attack and no evidence of crevice attack. The whole surface was coated with yellowish green crystalline deposits. However, there was no evidence of iron oxide formation on the surface. 
Page 6 of 12

Table 2. Post-Test Characterization of Solutions

\begin{tabular}{|c|c|c|}
\hline Test Solution & Material & Observations \\
\hline Nitric (3M) & A537 & $\begin{array}{l}\text { Liquid - Dark brown; Solids - Rusty, sludge; } \\
\mathrm{pH}=1.1\end{array}$ \\
\hline Nitric $(0.3 \mathrm{M})$ & A537 & $\begin{array}{l}\text { Liquid - Clear at top/dark brown at bottom; } \\
\text { Solids - none; } \mathrm{pH}=1.6\end{array}$ \\
\hline Oxalic(4\%), Nitric (3M) & A537 & Liquid - Dark brown; Solids - none; $\mathrm{pH}=1.2$ \\
\hline Oxalic(8\%), Nitric (3M) & A537 & $\begin{array}{l}\text { Liquid - Dark brown; Solids - none; } \mathrm{pH}= \\
0.65\end{array}$ \\
\hline Oxalic(12\%), Nitric (3M) & A537 & $\begin{array}{l}\text { Liquid - Dark brown; Solids - none; } \mathrm{pH}= \\
0.49\end{array}$ \\
\hline Oxalic(4\%), Nitric (0.3M) & A537 & Liquid - Lime green; Solids - none; $\mathrm{pH}=0.9$ \\
\hline Oxalic(8\%), Nitric (0.3M) & A537 & $\begin{array}{l}\text { Liquid - Lime green; Solids - none; } \mathrm{pH}= \\
0.84\end{array}$ \\
\hline Oxalic(12\%), Nitric (0.3M) & A537 & $\begin{array}{l}\text { Liquid - Lime green; Solids - crystals; } \mathrm{pH}= \\
0.71\end{array}$ \\
\hline Nitric $(3 \mathrm{M})$ & A285 & $\begin{array}{l}\text { Liquid - Dark brown; Solids - sludge on } \\
\text { bottom; } \mathrm{pH}=0.95\end{array}$ \\
\hline Nitric $(0.3 \mathrm{M})$ & A285 & $\begin{array}{l}\text { Liquid - Clear at top/coffee @ at bottom; } \\
\text { Solids - none; } \mathrm{pH}=1.9\end{array}$ \\
\hline Oxalic(4\%) and Nitric (3M) & A285 & $\begin{array}{l}\text { Liquid - Dark brown; Solids - none; } \mathrm{pH}= \\
1.04\end{array}$ \\
\hline Oxalic (8\%) and Nitric (3M) & A285 & Liquid - Dark brown; Solids - none; $\mathrm{pH}=1.0$ \\
\hline Oxalic(12\%) and Nitric (3M) & A285 & $\begin{array}{l}\text { Liquid - Dark brown; Solids - none; } \mathrm{pH}= \\
1.08\end{array}$ \\
\hline Oxalic(4\%) and Nitric (0.3M) & A285 & $\begin{array}{l}\text { Liquid - Lime green; Solids - none; } \mathrm{pH}= \\
0.65\end{array}$ \\
\hline Oxalic(8\%) and Nitric (0.3M) & A285 & $\begin{array}{l}\text { Liquid - Lime green; Solids - none; } \mathrm{pH}= \\
0.88\end{array}$ \\
\hline Oxalic(12\%) and Nitric (0.3M) & A285 & $\begin{array}{l}\text { Liquid - Lime green; Solids - sludge; } \mathrm{pH}= \\
0.5\end{array}$ \\
\hline
\end{tabular}


Page 7 of 12

(a)

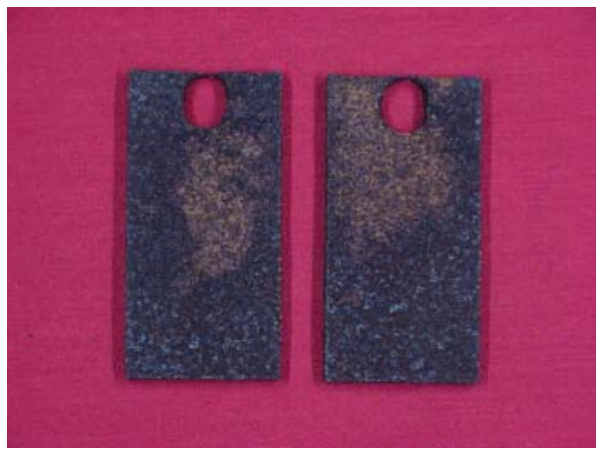

(b)

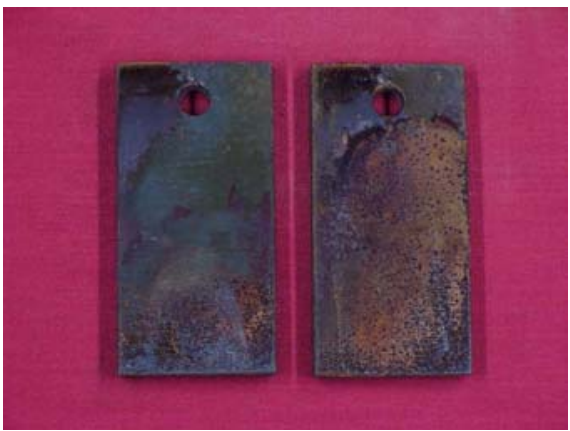

Figure 2. Photographs of A537 coupons exposed to (a) $3 \mathrm{M}$ nitric acid and (b) $0.3 \mathrm{M}$ nitric acid.

(a)

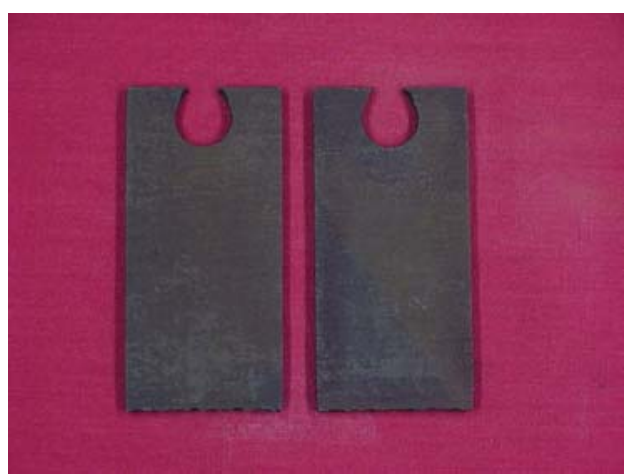

(b)

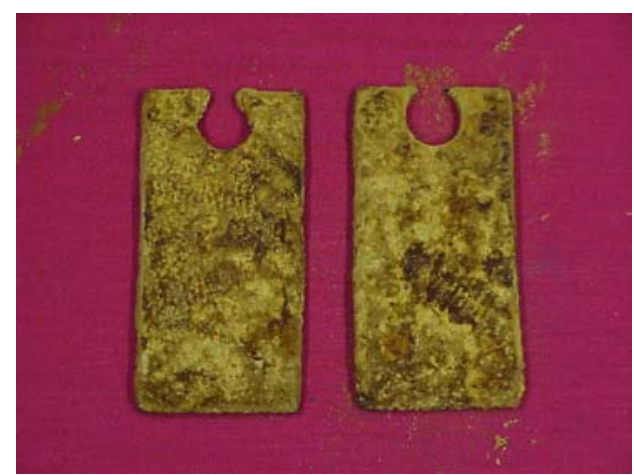

Figure 3. Photographs of coupons exposed to $3 \mathrm{M}$ nitric acid and 8 wt. \% oxalic acid. (a) A537 for 3 days and (b) A285 for 9 days.

(a)

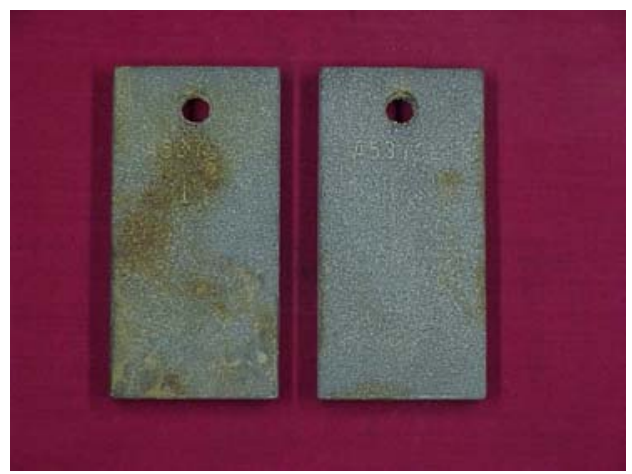

(b)

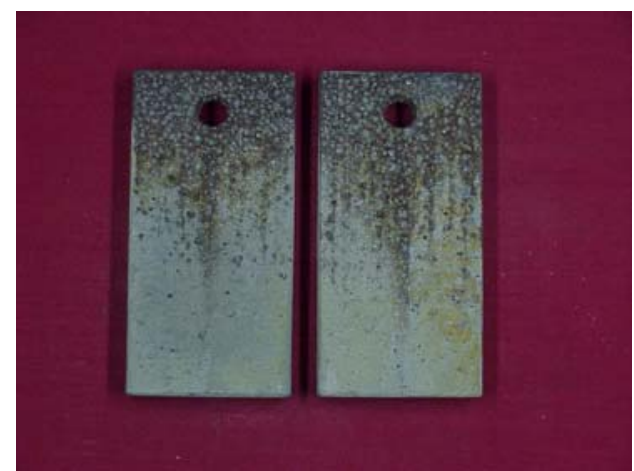

Figure 4. Photographs of A537 Carbon Steel Exposed to: (a) $0.3 \mathrm{M}$ nitric acid, 4wt.\% oxalic acid and (b) $0.3 \mathrm{M}$ nitric acid, 8 wt. \% oxalic acid. 
Page 8 of 12

\section{XRD Analysis of Surface Deposits}

The XRD scan on samples removed from the coupons immersed in $3 \mathrm{M}$ nitric acid revealed only an amorphous peak that may be an indication of iron. There were no indications of iron oxides. The scan on samples removed from coupons immersed in $3 \mathrm{M}$ nitric acid with various concentrations of oxalic acid indicated that there was a mixture of ferrous oxalate and iron present on the surface. The scan for samples removed from coupons immersed in $0.3 \mathrm{M}$ nitric acid with various concentrations of oxalic acid indicated that the surface deposits were primarily ferrous oxalate. Again there was no indication of iron oxides.

\section{Observations from Light Microscopy}

Figures 5-7 are micrographs of the coupons that reveal the morphology of the corroded surface after cleaning. Figure 5 shows the surface of a coupon that had been exposed to $3 \mathrm{M}$ nitric acid. The surface is rough and bumpy, indicative of general corrosion.

Coupons that had been immersed in $3 \mathrm{M}$ nitric acid with various amounts of oxalic acid were very similar in appearance to that of coupons immersed in the $3 \mathrm{M}$ nitric acid solution. The only exception was the coupon that had been exposed for 9 days rather than 3. Figure 6 shows the surface of this coupon. Several areas were evident where there appears to be a film present on the surface that has cracked and flaked off. Although it was not analyzed this film is likely ferrous oxalate.

Figure 7 shows the surface of a coupon that had been immersed in $0.3 \mathrm{M}$ nitric acid and 8 wt.\% oxalic acid. This sample is representative of other samples that had been immersed in $0.3 \mathrm{M}$ nitric acid and various amounts of oxalic acid. In addition to showing light general attack, several hemispherical shaped pits were observed. The maximum and average depth of these pits and the estimated pitting rate are shown in Table 3. It will be shown later that the pitting rate is insignificant in comparison with the general corrosion rate. In most cases the pits were surrounded with a ring of crystals that are assumed to be iron oxalate.

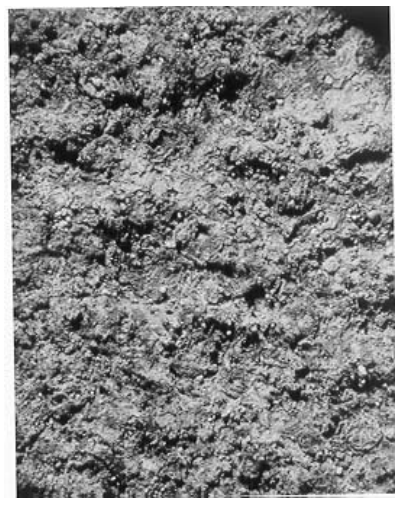

Figure 5. General Corrosion of A537 Coupon in 3 M Nitric Acid (12X). 
Page 9 of 12

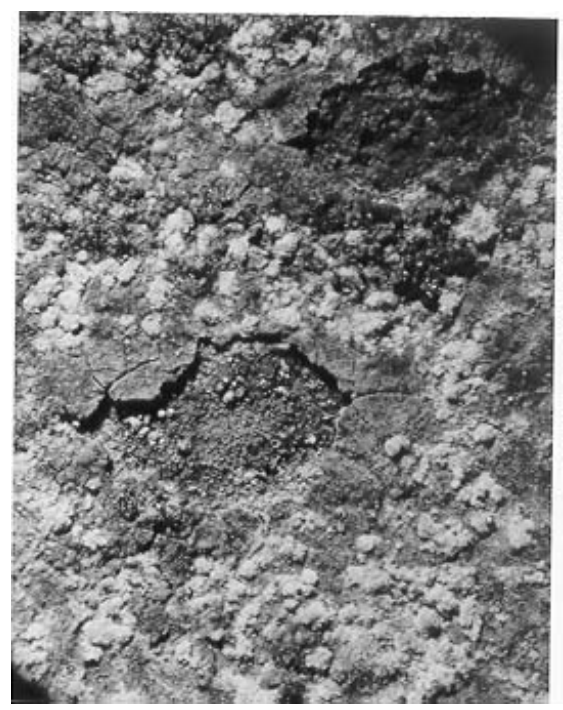

Figure 6. Breakdown of Ferrous Oxalate Film (12X).

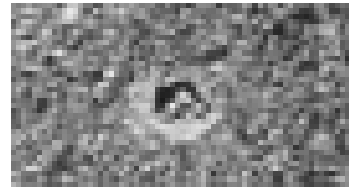

Figure 7. Small pits observed on coupons that were immersed in $0.3 \mathrm{M}$ nitric acid and 8 wt. \% oxalic acid (12X).

\section{Weight Loss Measurements}

The coupons were weighed after cleaning to determine the general corrosion rates in each solution. In all cases where the coupons were immersed in solutions that contained $3 \mathrm{M}$ nitric acid, the general corrosion was so severe that the stamped identification marks were no longer visible. In these cases, the total weight and total surface area of the 2 coupons were added together to obtain an average corrosion rate for the material in a given solution.

The corrosion rate was determined from the following equation.

$$
\text { Corrosion Rate }=\left(\left(3.45 \times 10^{6}\right)(\text { Weight Loss })\right) /((\text { Surface Area })(\text { Time })(\text { Density of Material }))
$$

The corrosion rates for each test are shown in Table 4. The corrosion rates appear to be reproducible as coupons from the same solution had similar corrosion rates. The corrosion rates for both types of steel were also similar for the same test solution. Some general trends that were observed include:

1) All solutions that contained $3 \mathrm{M}$ nitric acid produced very high general corrosion rates $(\sim 5$ to 8 inches per year).

2) As the oxalate concentration in the $3 \mathrm{M}$ nitric acid solutions increased, the corrosion rates also increased.

3) After 9 days in solution, the corrosion rate had decreased by a factor of nearly 3 as compared to the corrosion rate after 3 days.

4) The corrosion rate of steel in the $0.3 \mathrm{M}$ nitric acid is approximately an order of magnitude less than that observed in the $3 \mathrm{M}$ nitric acid solution. 


\section{Page 10 of 12}

5) The corrosion rate of steel in $0.3 \mathrm{M}$ nitric acid solutions with various concentrations of oxalic acid is 2 to 4 times less than that in $0.3 \mathrm{M}$ nitric acid alone. The maximum rate was observed at $8 \mathrm{wt}$. $\%$ oxalic acid, while the minimum was observed at $4 \mathrm{wt} . \%$.

To examine the severity of pitting in the coupons that exhibited small hemispherical pits, the pitting factor for each case was determined. The equation for the pitting factor is:

Pitting Factor $=($ pitting corrosion rate $) /($ general corrosion rate $)$

If this factor is on the order of 1 or less, pitting is considered to be minor and the form of corrosion is more likely general. Pitting factors that were calculated for both the maximum and average pitting rates are also shown in Table 3. The results show that the pitting is minor in comparison with general attack.

Table 3. Maximum and Average Pit Depths.

\begin{tabular}{|c|c|c|c|c|c|c|c|c|c|}
\hline Solution & Material & Coupon ID & $\begin{array}{l}\text { Maximum } \\
\text { Pit Depth } \\
(\mathrm{mm})\end{array}$ & $\begin{array}{l}\text { Maximum } \\
\text { Pit Depth } \\
\text { (mils) }\end{array}$ & $\begin{array}{l}\text { Pitting } \\
\text { Rate } \\
\text { (mpd) }\end{array}$ & $\begin{array}{l}\text { Pitting } \\
\text { Factor }\end{array}$ & $\begin{array}{l}\text { Ave. Depth } \\
\text { (mils) }\end{array}$ & \begin{tabular}{|l} 
Ave. \\
Pitting \\
Rate \\
(mpd)
\end{tabular} & $\begin{array}{l}\text { Ave. } \\
\text { Pitting } \\
\text { Factor }\end{array}$ \\
\hline \multirow[b]{2}{*}{ Nitric (3M) } & A537-CL1 & 1 & NA & NA & NA & $\mathrm{NA}$ & NA & NA & NA \\
\hline & A537-CL1 & 2 & NA & NA & NA & NA & NA & NA & NA \\
\hline Nitric (0.3M) & A537-CL1 & 3 & $\mathrm{NA}$ & NA & $\mathrm{NA}$ & NA & $\mathrm{NA}$ & NA & $\mathrm{NA}$ \\
\hline Nitric (0.3M) & A537-CL1 & 4 & $\mathrm{NA}$ & NA & NA & $\mathrm{NA}$ & $\mathrm{NA}$ & NA & $\mathrm{NA}$ \\
\hline \multirow[b]{2}{*}{ Oxalic (4\%) and Nitric (3M) } & A537-CL1 & 5 & $\mathrm{NA}$ & $\mathrm{NA}$ & $\mathrm{NA}$ & $\mathrm{NA}$ & $\mathrm{NA}$ & NA & $\mathrm{NA}$ \\
\hline & A537-CL1 & 6 & NA & NA & NA & NA & NA & NA & NA \\
\hline \multirow[b]{2}{*}{ Oxalic $(8 \%)$ and Nitric $(3 \mathrm{M})$} & A537-CL1 & 7 & $\mathrm{NA}$ & NA & NA & NA & $\mathrm{NA}$ & NA & $\mathrm{NA}$ \\
\hline & A537-CL1 & 8 & NA & NA & NA & $\mathrm{NA}$ & NA & NA & NA \\
\hline \multirow[b]{2}{*}{ Oxalic $(12 \%)$ and Nitric (3M) } & A537-CL1 & 9 & NA & NA & NA & NA & $\mathrm{NA}$ & NA & NA \\
\hline & A537-CL1 & 10 & NA & NA & NA & NA & NA & NA & $\mathrm{NA}$ \\
\hline Oxalic(4\%) and Nitric (0.3M) & A537-CL1 & 11 & 0.044 & 1.73 & 0.58 & 1.81 & 1.03 & 0.34 & 1.07 \\
\hline Oxalic $(4 \%)$ and Nitric (0.3M) & A537-CL1 & 12 & 0.066 & 2.60 & 0.87 & 2.47 & 1.46 & 0.49 & 1.39 \\
\hline Oxalic $(8 \%)$ and Nitric $(0.3 \mathrm{M})$ & A537-CL1 & 13 & 0.065 & 2.56 & 0.85 & 1.56 & 1.44 & 0.48 & 0.88 \\
\hline Oxalic $(8 \%)$ and Nitric $(0.3 \mathrm{M})$ & A537-CL1 & 14 & 0.075 & 2.95 & 0.98 & 1.80 & 1.46 & 0.49 & 0.89 \\
\hline Oxalic $(12 \%)$ and Nitric $(0.3 \mathrm{M})$ & A537-CL1 & 15 & 0.033 & 1.30 & 0.43 & 1.02 & 1.10 & 0.37 & 0.86 \\
\hline Oxalic $(12 \%)$ and Nitric (0.3M) & A537-CL1 & 16 & 0.041 & 1.61 & 0.54 & 1.30 & 0.79 & 0.26 & 0.63 \\
\hline \multirow[b]{2}{*}{ Nitric $(3 M)$} & A285-C & 1 & NA & NA & NA & NA & NA & NA & NA \\
\hline & A285-C & 2 & NA & NA & NA & NA & NA & NA & NA \\
\hline \begin{tabular}{|l} 
Nitric (0.3M) \\
\end{tabular} & A285-C & 3 & NA & NA & NA & NA & NA & NA & $\mathrm{NA}$ \\
\hline Nitric (0.3M) & A285-C & 4 & NA & NA & NA & $\mathrm{NA}$ & $\mathrm{NA}$ & NA & NA \\
\hline \multirow[b]{2}{*}{ Oxalic(4\%) and Nitric (3M) } & A285-C & 5 & NA & NA & NA & NA & NA & NA & NA \\
\hline & A285-C & 6 & NA & NA & NA & NA & NA & NA & $\mathrm{NA}$ \\
\hline \multirow[b]{2}{*}{ Oxalic $(8 \%)$ and Nitric $(3 \mathrm{M})^{*}$} & A285-C & 7 & NA & NA & $\mathrm{NA}$ & $\mathrm{NA}$ & $\mathrm{NA}$ & NA & $\mathrm{NA}$ \\
\hline & A285-C & 8 & NA & $\mathrm{NA}$ & $\mathrm{NA}$ & $\mathrm{NA}$ & $\mathrm{NA}$ & NA & $\mathrm{NA}$ \\
\hline \multirow[b]{2}{*}{ Oxalic $(12 \%)$ and Nitric (3M) } & A285-C & 9 & NA & NA & NA & NA & NA & NA & $\mathrm{NA}$ \\
\hline & A285-C & 10 & $\mathrm{NA}$ & NA & NA & $\mathrm{NA}$ & $\mathrm{NA}$ & NA & NA \\
\hline Oxalic $(4 \%)$ and Nitric (0.3M) & A285-C & 11 & 0.047 & 1.85 & 0.62 & 2.20 & 1.14 & 0.38 & 1.36 \\
\hline Oxalic (4\%) and Nitric (0.3M) & A285-C & 12 & NA & NA & NA & NA & $\mathrm{NA}$ & NA & $\mathrm{NA}$ \\
\hline Oxalic $(8 \%)$ and Nitric (0.3M) & A285-C & 13 & $\mathrm{NA}$ & NA & NA & $\mathrm{NA}$ & NA & NA & $\mathrm{NA}$ \\
\hline Oxalic $(8 \%)$ and Nitric $(0.3 \mathrm{M})$ & A285-C & 14 & 0.049 & 1.93 & 0.64 & 1.21 & 1.41 & 0.47 & 0.88 \\
\hline Oxalic $(12 \%)$ and Nitric (0.3M) & A285-C & 15 & 0.042 & 1.65 & 0.55 & 1.24 & 1.18 & 0.39 & 0.89 \\
\hline Oxalic $(12 \%)$ and Nitric $(0.3 \mathrm{M})$ & A285-C & 16 & 0.048 & 1.89 & 0.63 & 1.39 & 1.07 & 0.36 & 0.78 \\
\hline
\end{tabular}

* 9 day test

$\mathrm{N} / \mathrm{A}=$ No pits were observed. 
Page 11 of 12

Table 4. General Corrosion Rates

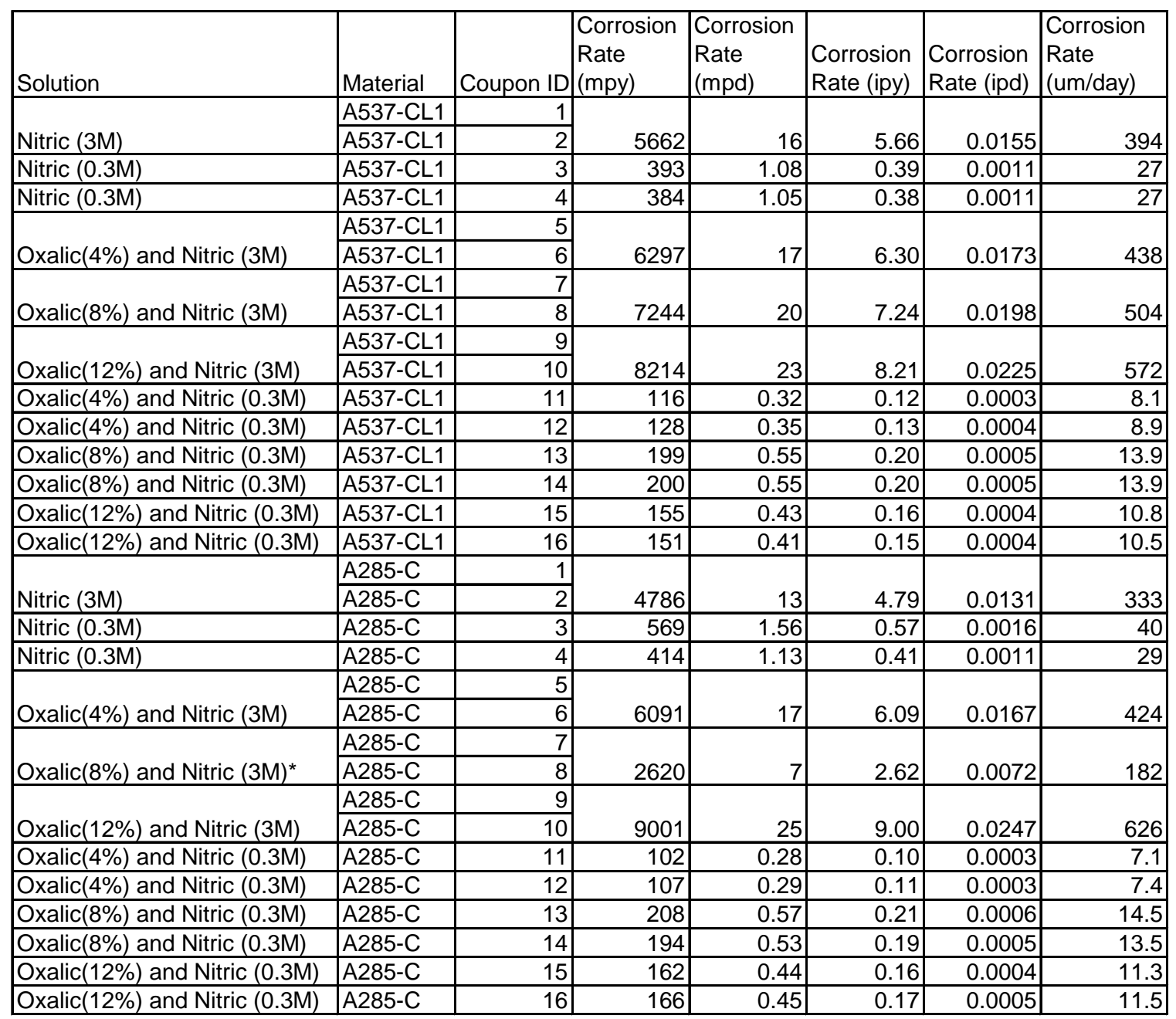

* 9 day test

\section{Discussion}

Several conclusions may be drawn from the results of these scoping experiments that could apply to acid cleaning of the sludge heel in waste tanks. The one unknown that could not be evaluated from these tests is the effect dissolving the metal oxides from the sludge will have on the corrosion rate of the iron. This effect will be examined in future testing.

Solutions that contain on the order of $3 \mathrm{M}$ nitric acid essentially dissolve the iron. During the first 3 days, ferrous oxalate does not precipitate on the surface to a great extent, and thus the corrosion rate remains high even in solutions that contain oxalic acid. It appears that the dark color of the solution (due to the high dissolution rate of the iron) may inhibit the precipitation of the ferrous oxalate film that is dependent upon visible light for formation. Between 3 and 9 days it appears that a ferrous oxalate film begins to form in the combined acid solution, thereby depressing the corrosion rate. However, this film was observed to be rather unstable and may flake off resulting in pitting over longer exposure times. Based on these results, utilization of solutions that contain on the order of $3 \mathrm{M}$ nitric acid would probably not be advisable. 
Page 12 of 12

The more dilute nitric acid solutions have significantly lower general corrosion rates. In addition, the presence of oxalic acid seems to result in a ferrous oxalate film that depresses the corrosion rate even further. It is unknown if the small pits that were observed on some of the coupons would begin to grow significantly if the exposure time were increased. From these results, further testing in dilute nitric acid solutions in combination with oxalic acid appears to be warranted.

\section{Conclusions}

The coupon immersion tests that were performed suggest that oxalic acid may be an effective inhibitor for carbon steel in dilute nitric acid solutions. Essentially no passivation was observed during the first 3 days in the $3 \mathrm{M}$ nitric acid solutions. More testing at better defined sludge removal conditions (i.e., perhaps higher temperatures, different contact times and other species present) is needed to evaluate the recommendation further. Depending on how much $\mathrm{NO}_{\mathrm{X}}$ is released, corrosion of carbon steel in the vapor space should also be investigated. Additionally studies that investigate sludge and fissile material dissolution in these dilute nitric acid/oxalic acid solutions are necessary.

\section{Acknowledgements}

The authors wish to acknowledge the assistance of J. C. Piercy, T. DeMaere, V. Timmerman, B.C. Miller, and T. B. Curtis during the performance of these tests.

Data from laboratory tests are recorded in notebook WSRC-NB-2000-00185.

\section{References}

1. U. R. Evans, "Behavior of Metals in Nitric Acid" in Trans. Faraday Society. Vol. 40, pp. 120-130, 1944.

2. H. H. Uhlig, Corrosion Handbook, The Electrochemical Society, New York, NY, pp. 133-134, 1948.

3. H. D. Smith, R. L. Russell, and G. K. Patello, "Evaluation of Hydrogen Gas Generation from Oxalic Acid Contact with the Carbon Steel of a High Level Waste Storage Tank", in Environmental Issues and Waste Management Technologies in the Ceramic and Nuclear Industries, Eds. J. C. Marra and G.T. Chandler, Ceramic Transactions, Vol. 93, pp. 221-227, 1999.

4. M. R. Elmore, "Corrosion of Mild Steel in Simulated Cesium Elution Process Solutions", PNNL11284, September 1996.

5. M. R. Elmore, et. al., "Fiscal Year 1995 Laboratory Scale Studies of Cs Elution in Tank 8D-1 and Sludge Dissolution in Tank 8D-2”, PNNL-10945, April 1996.

6. ASTM Standard G31, "Standard Practice for Laboratory Immersion Corrosion Testing of Metals". 